\title{
New species of Restionaceae from Western Australia
}

\author{
K.A. Meney, J.S. Pate, K.W. Dixon
}

\begin{abstract}
Meney, K.A. ${ }^{1}$, Pate, J.S. ${ }^{2}$, and Dixon, K.W. ${ }^{1}\left({ }^{1}\right.$ Kings Park and Botanic Garden, West Perth, Western Australia 6005; ${ }^{2}$ Botany Department, University of Western Australia, Nedlands, Western Australia 6907) 1996. New species of Restionaceae from Western Australia. Telopea 6(4): 649-666. Nine new taxa of Restionaceae from south-western Australia are described for the first time. The paper outlines diagnostic characteristics, ecological features and conservation status of each of the following species: Desmocladus glomeratus K.W. Dixon \& K.A. Meney, Harperia ferruginipes K.A. Meney \& J.S. Pate, Hypolaena robusta K.A. Meney \& J.S. Pate, Lepidobolus basiflorus J.S. Pate \& K.A. Meney, Lepidobolus spiralis K.A. Meney \& K.W. Dixon, Leptocarpus crassipes J.S. Pate \& K.A. Meney, Loxocarya albipes J.S. Pate \& K.A. Meney, Loxocarya magna K.A. Meney \& K.W. Dixon, Onychosepalum microcarpum K.A. Meney \& J.S. Pate. Illustrations accompany each description.
\end{abstract}

\section{Introduction}

This paper describes nine new taxa of the predominantly Southern Hemisphere family, Restionaceae: Desmocladus glomeratus, Harperia ferruginipes, Hypolaena robusta, Lepidobolus basiflorus, Lepidobolus spiralis, Leptocarpus crassipes, Loxocarya albipes, Loxocarya magna, Onychosepalum microcarpum. Formal descriptions and illustrations of each taxon are provided alongside information on distribution, ecological preferences and conservation status. The genus Desmocladus Nees is being revised by B.G. Briggs and L.A.S. Johnson for the majority of the species that have until now been known as Loxocarya.

Together with the taxonomic revisions of the family near completion by B.G. Briggs and L.A.S. Johnson for the Flora of Australia, this paper contributes to a now comprehensive study of the phytogeography, taxonomy and biology of the Australian Restionaceae. In the past 12 years, the family in Australia has gone from 115 known species and 20 genera (Johnson and Briggs 1983) to 147 species and possibly 27 genera (Briggs and Johnson pers. comm.). Significant rediscoveries in this period included Restio abortivus Nees and Restio chaunocoleus F. Muell. which had eluded botanists since their type collections in the mid 19th century.

Desmocladus glomeratus K.W. Dixon \& K.A. Meney, sp. nov.

Planta dioica, rhizomate brevi, repente, dense villoso, culmis erectis ramosis, pubescentibus, vaginis ovatis sub apice pilis fasciculatis, indutis instructis ramis et spiculis ad nodos plusminusve glomerose aggregatis.

Type: South-western Western Australia, Northampton (28 $\left.21^{\circ} \mathrm{S} 114^{\circ} 38^{\prime} \mathrm{E}\right)$, Meney $\mathcal{E}$ Dixon KM 909 (female plant), 10 August 1990 (holotype KPBG; isotype PERTH). Growing in shallow sandy soils over laterite.

Habit: Plants dioecious, fruticose, densely tufted, glomerose, approximately $40 \mathrm{~cm}$ tall, $20-30 \mathrm{~cm}$ in diameter. Rhizome compact, densely villous with ferruginous to pale hairs, $1.8-2.1 \mathrm{~mm}$ in diameter; scale leaves straw-coloured, broadly lanceolate, overlapping, $0.8 \mathrm{~mm}$ long. Culms terete, branched, pubescent and finely scabrous, 
pale green, more or less erect, $30-50 \mathrm{~cm}$ long; culm nodes more or less equidistant, 10-15 per culm and each giving rise to branchlets; cataphylls straw-coloured, overlapping, ribbed and lanceolate, $3 \mathrm{~mm}$ long; culm sheaths light brown to strawcoloured, striate, ovate ( $3 \mathrm{~mm}$ wide, $9 \mathrm{~mm}$ long), hairy on outer surface and margins with a dense apical fringe of longer hairs (1-1.3 mm long), apex aristate, sparsely hairy, lamina diverging from sheath, 7-12 mm long; culm branchlets bearing lateral

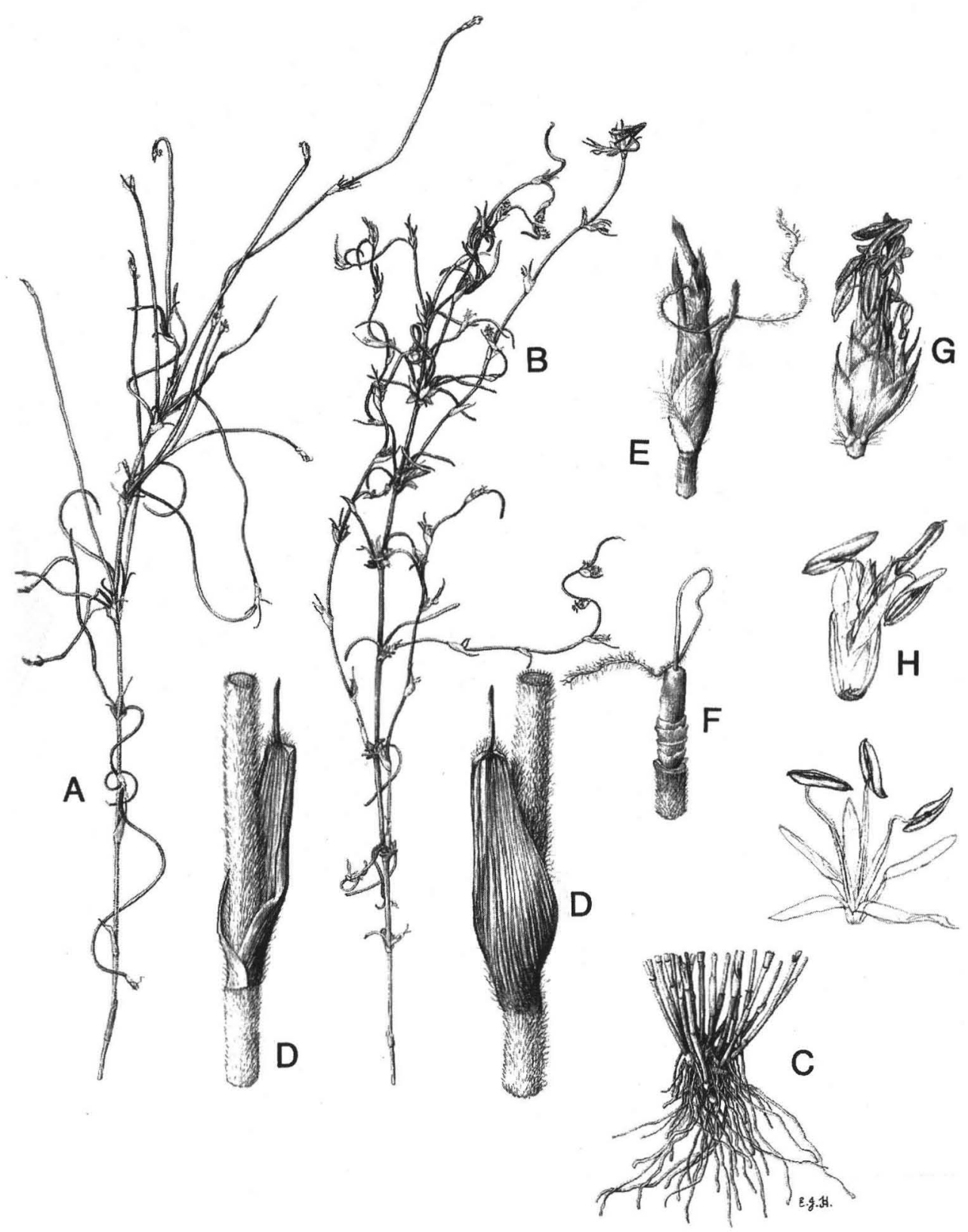

Fig. 1. Desmocladus glomeratus K. W. Dixon \& K. A. Meney. A, female culm ( $\times 0.6)$; B, male culm $(\times 0.6)$; C, rhizome $(\times 0.6)$; $\mathbf{D}$, culm sheath and lamina $(\times 1.8)$; $\mathbf{E}$, female spikelet $(\times 5)$; $\mathbf{F}$, female flower (x 5); $\mathbf{G}$, male spikelet $(\times 5)$; $\mathbf{H}$, male flower $(\times 5)$. 
terete branches and flattened irregular branchlets of a higher order in texture and surface similar to culms, sheaths usually narrower. Spikelets, branches and branchlets arising together giving the nodes a glomerose appearance. Male Spikelets sessile, clustered in axils of culm sheaths, or terminal on branchlets, 1-5 per cluster, broadly fusiform, 4-6 mm long, 1-1.5 mm broad, each subtended by 20-30 imbricate rigid hyaline glumes; glumes pale straw in colour, with a brown mucro, 3-3.4 mm long, 1-1.2 mm wide. Male flowers sessile, 3-6 per spikelet; tepals 6, 3-6 mm long, linearlanceolate; stamens 3, exserted. Female spikelets similar to males, fusiform, 4-5 mm long, $0.8-1 \mathrm{~mm}$ wide; glumes $4-7$, closely adpressed, 1.5-3.5 $\mathrm{mm}$ long with a 1.5-2.5 mm long mucro, uppermost glumes fertile, subequal, hairy on outer surfaces; lower glumes with broad, green flattened apex. Female flowers one per spikelet; tepals 6, linear-lanceolate, 3-6 mm long; stigma unbranched, red 4-7 mm long, plumose. Fruit a uniovulate nut, $5 \mathrm{~mm}$ long, $1 \mathrm{~mm}$ wide, elongate with a blunt apex, outer fruit wall ribbed; seed brown to cream coloured.

Flowering: August to October. Seed-shed: October to November. Seedlings: not encountered in habitat.

Affinities: Desmocladus glomeratus is most similar to Desmocladus virgatus L.A.S. Johnson and B.G. Briggs ined., but lacks verticillate arrangement of culm branches and has sessile spikelets and a more lax habit than the latter species.

Ecological Features: The species is known from only one location in sand over laterite in heathland at Howatharra Hill north-east of Geraldton. Plants are killed by fire and regenerate from seed.

Conservation status: The species is in urgent need of further survey to determine the extent of its distribution and conservation status. For the present it should be gazetted as rare and endangered.

Etymology: The specific epithet is derived from the Latin term glomeratus, formed into a ball, referring to the clustered arrangement of spikelets and branchlets.

\section{Harperia ferruginipes K. A. Meney \& J. S. Pate, sp. nov.}

Planta dioica caespitosa, rhizomatibus reptantibus tomentosis, pilis ferrugineis, culmis valde ramosis, vaginis adpressis lato interiori pilis fasciculatis praeditis, spiculis singulis terminalibus vel axillaribus, numerosis in eadem culmo.

Type: South-western Western Australia, S.W. Botanical Province between Geraldton $\left(28^{\circ} 46^{\prime} \mathrm{S} 114^{\circ} 37^{\prime} \mathrm{E}\right)$ and Mullewa (28 32'S 115 $\left.30^{\prime} \mathrm{E}\right)$ Meney \& Pate KM9401, 19 April 1994, (holotype KPBG; isotype PERTH). Growing in open heathland on red sandy loams.

Habit: Plants dioecious forming dense low clumps with a stout creeping rhizome, clumps approximately $0.5 \mathrm{~m}$ tall, usually $30-80 \mathrm{~cm}$ across. Rhizome creeping with wellspaced culms (1-2 cm apart), 6-10 mm in diameter, densely villous with long redbrown to ginger hairs; scale leaves broadly triangular, overlapping covered with dense ginger hairs; cataphylls 8-14 mm long with covering of ginger hairs prominent above soil surface. Culms terete, hollow with distinctive multilacunar pith, yellow-green, 30-60 cm long, 1.5-2.5 mm diameter, upper half of culms many-branched, sinuose, smooth; lower 2-3 internodes with fine covering of short ginger hairs, culm surface finely rugose; culm nodes more or less equidistant, 10-15 per culm; culm sheaths orange-brown when young, ageing dull grey, appressed, 8-15 mm long with purple ring at base, enclosing a tuft of ginger to white hairs borne at the nodes, lower culm sheaths with basal covering of ginger hairs; lamina narrow, spiny, divergent, $2-3 \mathrm{~mm}$ long, dark purple. Male spikelets mostly solitary, terminal or axillary, well-spaced, 1-2 cm apart, numerous per culm, 3-8 per culm branchlet, ovoid, 4-6 mm long; glumes orange with a fringe of white hairs, bracts and glumes bearing spines, mucro 
1-1.5 mm long, rigid. Male flowers sessile, 6-12 per spikelet, upper flowers usually sterile; tepals 6, broadly lanceolate, 1-1.3 mm long; stamens 3, exserted. Female spikelets solitary, sessile, terminal or axillary and well-spaced, $0.5-2 \mathrm{~cm}$ apart, elongate, 5-8 $\mathrm{mm}$ long; bracts and glumes identical to those of male plant. Female flowers sessile, 1-2 fertile per spikelet, uniovulate; style single $2-3 \mathrm{~mm}$ long, with an exserted, often coiled, white, flattened, papillate stigma. Fruit an elongate nut; seeds one per fruit.

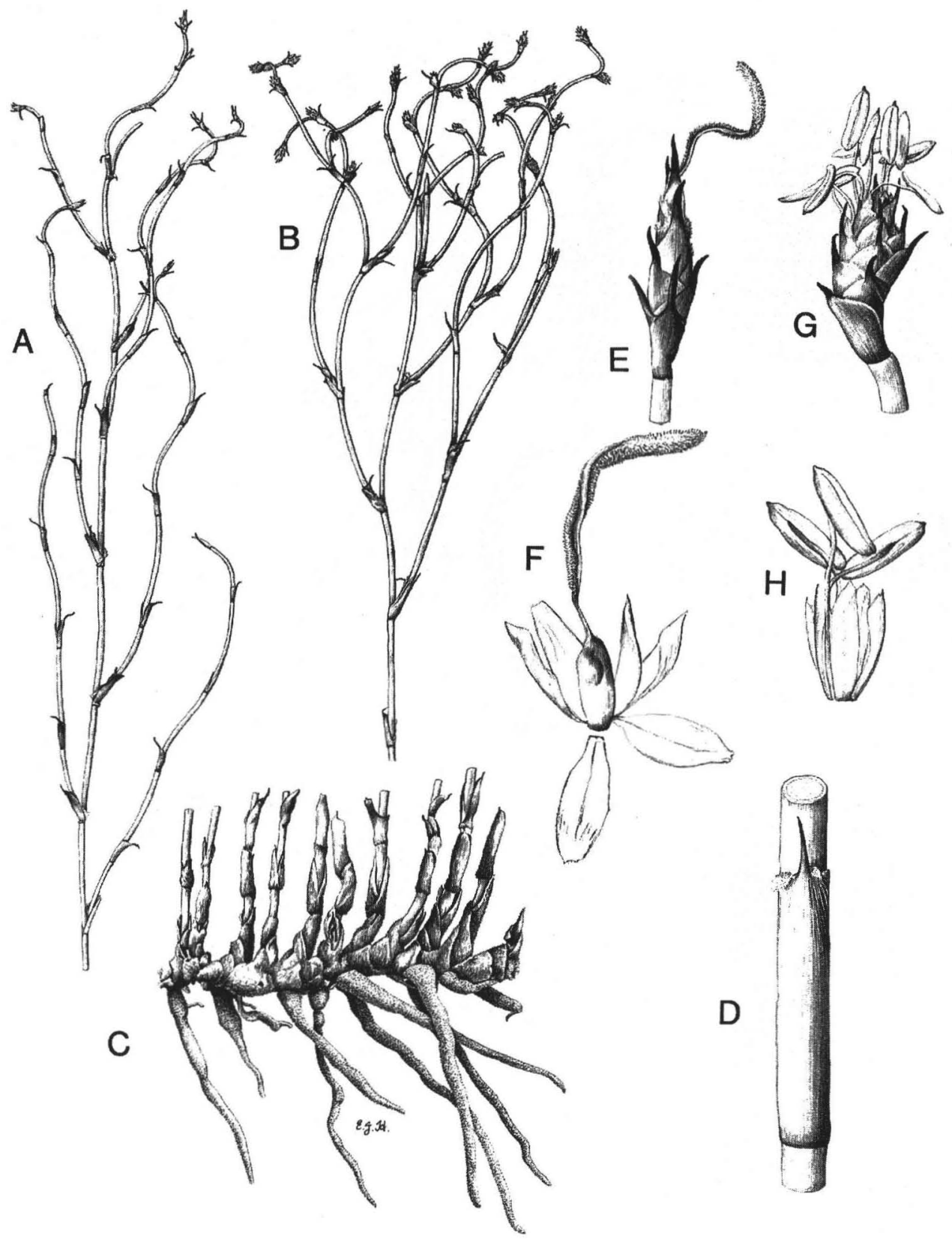

Fig. 2. Harperia ferruginipes K. A. Meney \& J. S. Pate; A, female culm $(\times 0.6)$; B, male culm $(\times 0.6)$; C, rhizome $(\times 0.5)$; D, culm sheath $(\times 3.5)$; E, female spikelet $(\times 5)$; F, female flower $(\times 14)$; $\mathbf{G}$, male spikelet $(\times 5)$; $\mathbf{H}$, male flower $(\times 14)$. 
Flowering: Autumn (April to May). Seed-shed: September to October. Seedlings: not seen in habitat.

Affinities: Most similar to H. lateriflora W. Fitzg. in culm and spikelet morphology but immediately distinguishable by its densely hairy rhizomes and robust multibranched culms. This species is typical of the genus Harperia in gross morphology, spikelet characteristics and culm anatomy.

Ecological features: Known from only one locality in open heathland on red sandy loam soil between Geraldton and Mullewa. Growing with Lepidobolus basiflorus, L. chaetocephalus F. Muell. ex Benth. and L. preissianus Nees. Rhizomes contain dense starch reserves, indicating that the plants probably survive fire.

Conservation status: Probably highly restricted and known presently from only one small unreserved population with less than 200 plants. Further survey and gazetting of conservation priority status is urgently required.

Etymology: The specific epithet is derived from the Latin ferrugo, ferruginis, rust and pes, a foot, referring to the densely tomentose rust coloured rhizomes.

\section{Hypolaena robusta K. A. Meney \& J. S. Pate, sp. nov.}

Planta dioica, valida, rhizomatibus crassis repentibus, culmis distantibus, parce ramosis, ramis tricompressis, vaginis elongatis ad apicem nitidis, caducis, spiculis terminalibus vel axillaribus in parte superiosi culmi, masculinis pendulis, foemininis erectis.

Type: South-western Western Australia, S.W. Botanical Province near Badgingarra (30²4'S 115³3'E), Meney \& Pate KM 9092, 6 September 1990, (holotype KPBG; isotype PERTH). Inconspicuous in deep white sands.

Habit: Plants dioecious, tall with sparse culms on stout rhizomes. Rhizome creeping, with widely spaced culms $5-8 \mathrm{~mm}$ in diameter, cream-coloured with sparse white hairs under scale leaves; scale leaves clasping, triangular, shiny orange-brown with scarious margins, striate in upper outer portions, $1.5 \mathrm{~cm}$ long; cataphylls similar to scale leaves, but longer, $1.8-2.5 \mathrm{~cm}$ long, fragmenting with age. Culms densely tomentose on lower internodes, sparingly branched, main culms terete, branches semi-flattened, blue-green, 50-70 cm long, 2.5-3.0 mm diameter; culm nodes more or less equidistant 7-8 cm long; culm sheaths grey, scarious, 20-30 mm long, ribbed, especially near flared apex, lamina short, $2 \mathrm{~mm}$ long, deciduous. Male spikelets in short terminal or axillary clusters, pendulous on densely tomentose pedicels, up to 20 spikelets per culm, bronze, ovoid, 7-9 mm long; glumes rust-coloured narrow-lanceolate with scarious margins, up to $3 \mathrm{~mm}$ long, mucro $0.3 \mathrm{~mm}$ long. Male flowers sessile, more than 20 per spikelet; tepals 6, 1.5-2 mm long, broadly lanceolate; stamens 3. Female spikelets erect, shortly pedicillate, solitary or paired on upper portions of branchlets, less than 5 per branchlet, linear, 10-12 mm long; glumes obovate, appressed, 8-10 mm long, mucro $1 \mathrm{~mm}$ long. Female flowers with tepals 6, 2-3 mm long, obovate; style with 3 branches, fused at base, stigma purple. Fruit an arillate nut, $5 \mathrm{~mm}$ long.

Flowering: September-October. Seed-shed: September-October. Seedlings: not observed.

Affinities: Probably closest to $H$. exsulca R.Br. but readily distinguished by stout rhizomes, widely spaced culms, and sparse inflorescences.

Ecological features: Infrequent inconspicuous species in dense heath on deep white sands of the northern sandplains in the Badgingarra region. Known from only a few small populations. Starch is present in rhizomes and plants resprout after fire.

Conservation status: Probably very restricted and in need of further survey and assessment of requirements for conservation.

Etymology: The specific epithet is derived from the Latin robustus, robust, referring to the stout rhizome and culms. 


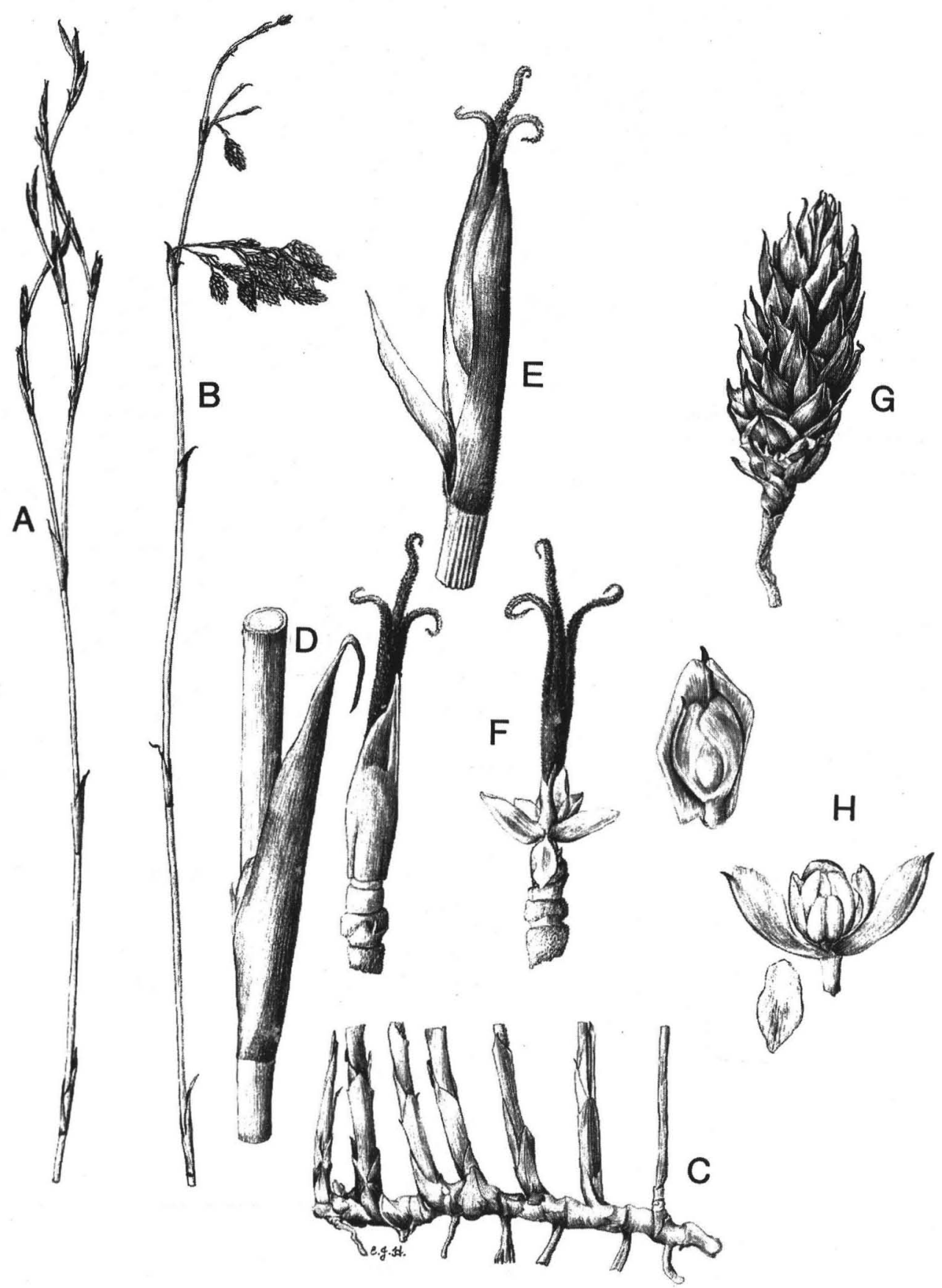

Fig. 3. Hypolaena robusta K.A. Meney \& J.S. Pate. A, female culm $(\times 0.5)$; B, male culm $(\times 0.5)$; C, rhizome $(\times 0.75)$; $D$, culm sheath $(\times 3)$; E, female spikelet $(\times 5) ; \mathbf{F}$, female flower $(\times 4.5)$; $\mathbf{G}$, male spikelet $(\times 5)$; $\mathbf{H}$, male flower $(\times 4.5)$. 
Lepidobolus basiflorus J.S. Pate \& K.A. Meney, sp. nov.

Planta dioica caespitosa, rhizomatibus villosis pilis adscendentibus, culmis superioribus sterilibus, valde sinuosis ad circinatis, culmis inferioribus abbreviatis, erectis et floriferis, vaginis lanceolatis, nitidis, cito caducis, spiculis sessilibus vel breviter pedicellatis bracteis spinis prominentibus.

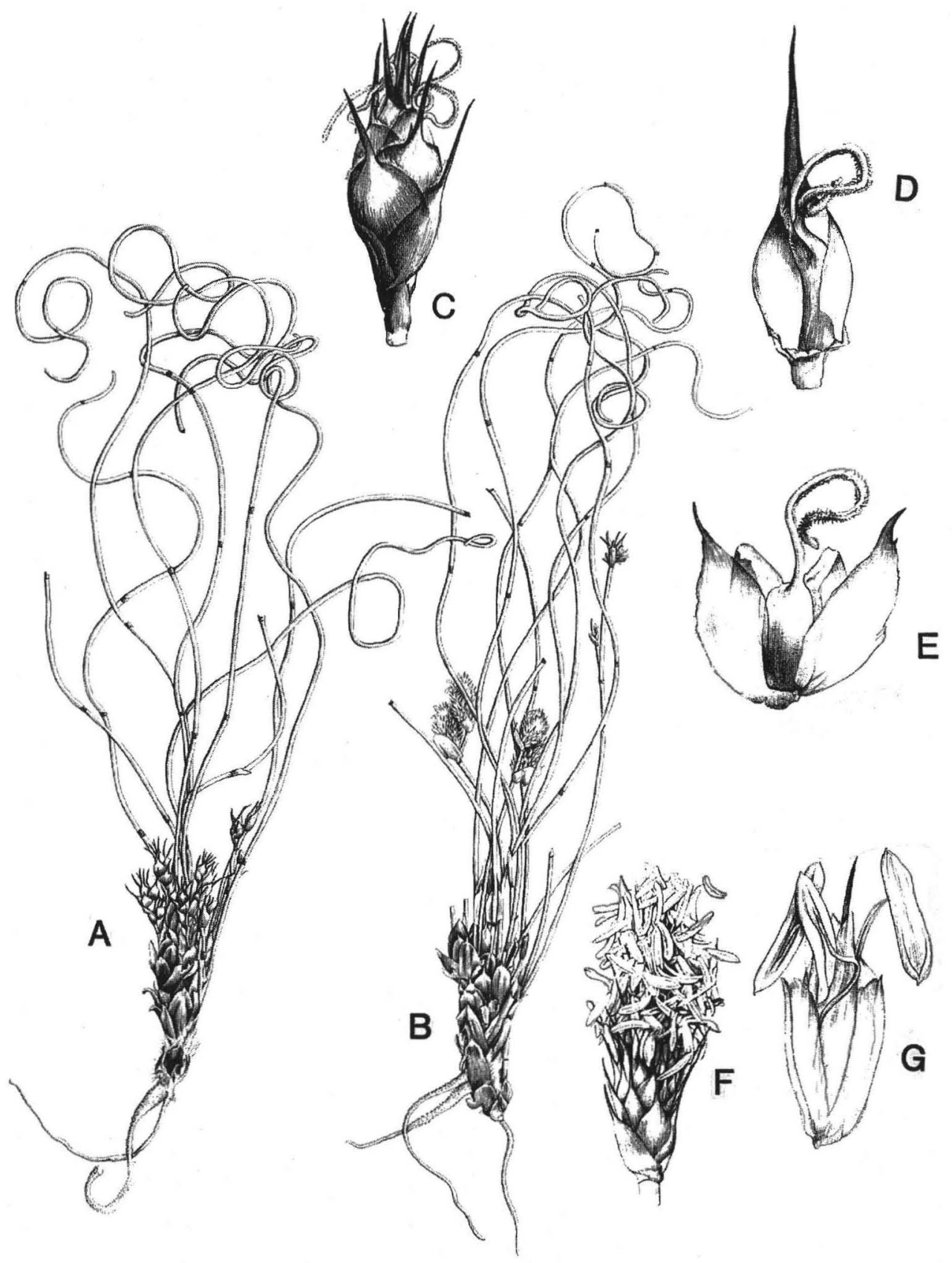

Fig. 4. Lepidobolus basiflorus J.S. Pate \& K.A. Meney. A, female plant $(\times 0.7)$; B, male plant $(\times 0.7)$; C, female spikelet $(\times 3.8)$; D \& E, female flowers $(\times 4.5)$; F, male spikelet $(\times 3.8)$; G, male flower $(\times 4.5)$. 
Type: South-western Western Australia, S.W. Botanical Province between Geraldton $\left(28^{\circ} 46^{\prime} \mathrm{S} 114^{\circ} 37^{\prime} \mathrm{E}\right)$ and Mullewa (28 32'S 115³0'E), Pate \& Meney KM9402, 19 April 1994, (holotype KPBG; isotype PERTH). Growing in open heathland on red sandy loam.

Habit: Plants dioecious, densely tufted to $30 \mathrm{~cm}$, with conspicuous, short basal flowering culms and interwoven canopy of longer tightly coiled vegetative culms. Rhizome 1-2 mm diameter, ascending, red-brown with $5 \mathrm{~mm}$ long white hairs; scale leaves broadly truncate, chocolate-brown with a smooth outer layer and a straw-coloured inner layer, ribbed on inner surface, $10 \mathrm{~mm}$ long, non-deciduous; cataphylls similar to scale leaves but up to $1.3 \mathrm{~mm}$ long with an inner tuft of long hairs, non-deciduous, chocolate-brown. Culms terete, hollow at base, $0.3-0.5 \mathrm{~mm}$ diameter; tall culms mostly sterile, coiled, unbranched, light-green, $20-30 \mathrm{~cm}$ long, lower two internodes densely tomentose, upper internodes finely marbled; reproductive culms $2-5 \mathrm{~cm}$ long in females, 5-6 cm long in males, lower portions including female spikelets often partly covered by sand; nodes on vegetative culms 6-11, more or less equidistant 3-5 cm apart; culm sheaths lanceolate, flared, brown at base, straw-coloured at apex, 6-10 mm long with a short lamina, sheaths quickly deciduous on upper parts of culm, usually persistent on lower part, purple ring at nodes remaining after abscission of sheaths. Male spikelets sessile or shortly pedicellate 2-4 per reproductive culm, axillary on upper $2 \mathrm{~cm}$, subglobose 10-15 mm long, 5-7 mm wide, subtended by a straw-coloured, elongate bract, $0.4-0.6 \mathrm{~mm}$, bearing a prominent lamina $1.5 \mathrm{~mm}$ long; glumes truncate, $6 \mathrm{~mm}$ long with a soft bristle-like mucro 1-2 mm long. Male flowers sessile, up to 20 per spikelet; tepals 4, $2.5 \mathrm{~mm}$ long, linear-lanceolate; stamens 3, exserted. Female spikelets sessile or shortly pedicellate, 2-4 per culm, more or less equally spaced, broadly elongate, 10-15 mm long, 3-5 mm wide, subtending bract similar to that of males; glumes chocolate-brown with distinctive upper green portion and apical tuft of inconspicuous white hairs, lower glumes sterile; mucro rigid, spiny, 2-4 mm long, purple-brown. Female flowers sessile, 2-4 per spikelet; tepals 4, linear-lanceolate, straw-coloured, 2-5 mm long; style unbranched, red, up to $9 \mathrm{~mm}$ long. Fruit a unilocular nut.

Flowering: Autumn (April-May). Seed-shed: September-October. Seedlings: not seen.

Affinities: L. basiflorus is morphologically similar to L. chaetocephalus and L. preissianus which both co-occur at its one known locality. Distinguished from L. preissianus by erect rather than creeping rhizomes, and from L. chaetocephalus by smaller elongate male spikelets. The basal flowering culms and taller vegetative culms are unique.

Ecological features: Only known from one population in open heath on sand and sandy loam soils between Geraldton and Mullewa. Starch is present in both rhizome and culms but fire response is unknown.

Conservation status: Probably very restricted. The only known population is unreserved with less than 100 plants. Further survey and immediate classification as a high conservation priority species is urgently required.

Etymology: The specific epithet is from the Latin basis, base and florus, flowered and refers to the unusual basal flowering habit.

\section{Lepidobolus spiralis K. A. Meney \& K. W. Dixon, sp. nov.}

Planta dioica rhizomatibus breviter reptantibus, culmis dense fasciculatis, eramosis, sinuosis ad subspiraliter curvatis, vaginis truncatis, nitidis, caducis, spiculis sessilibus, singulis, caducis. Spiculae foemineae glumis prominenter refracte spinescentibus.

Type: South-western Western Australia. Frank Hann National Park, East of Lake King (3305'S 119²0'E), Meney \& Dixon KM293, 2 November 1990, (holotype KPBG; isotype PERTH). Growing in heathland on deep yellow sands. 

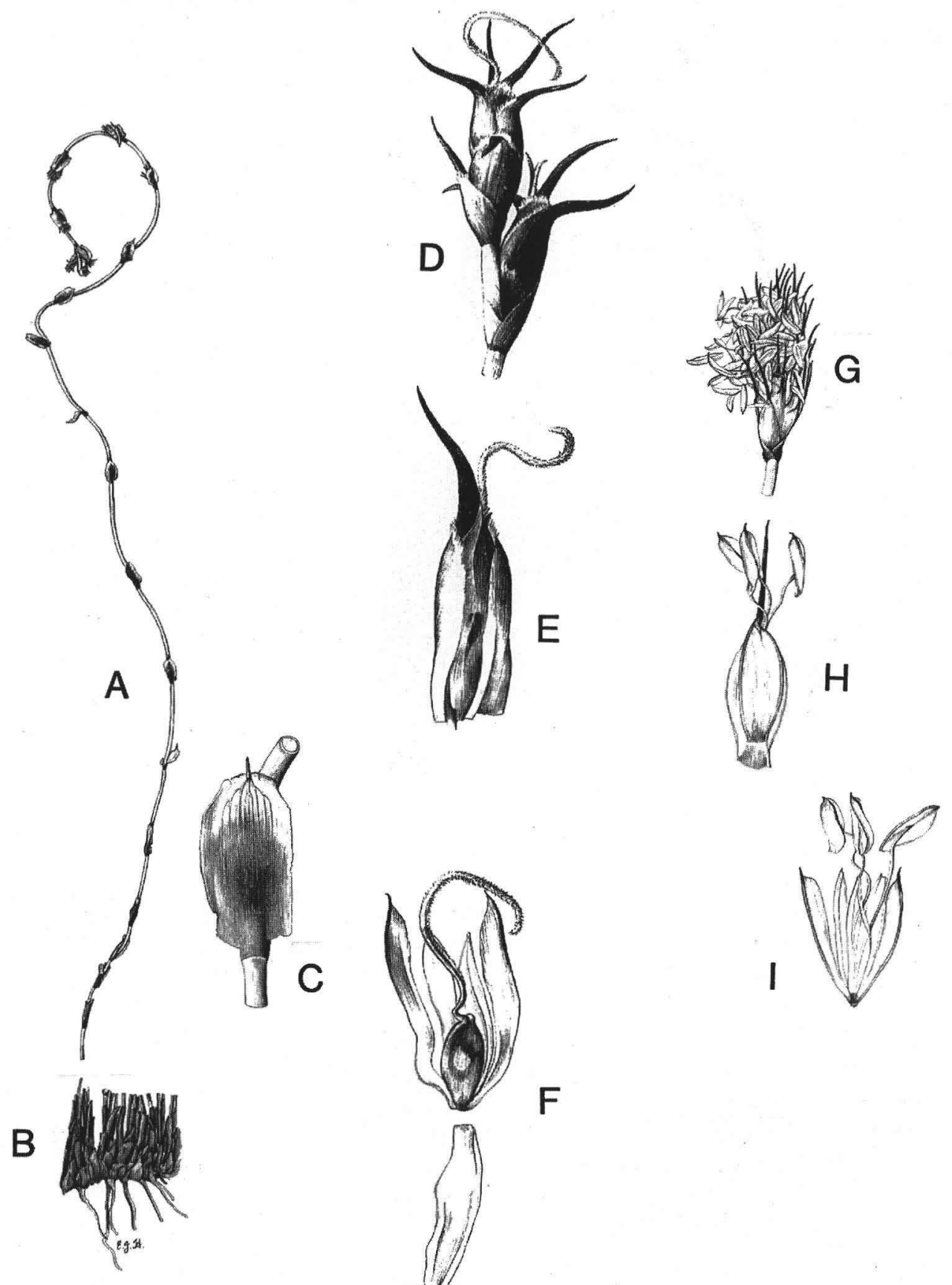

Fig. 5. Lepidobolus spiralis K.A. Meney \& K.W. Dixon. A, female culm $(\times 0.4)$; B, rhizome $(\times 2.4)$; C, culm sheath $(\times 5)$; D, female spikelets $(\times 12)$; E \& F, female flowers $(\times 12)$; G, male spikelet $(\times 5)$; H \& I, male flowers $(\times 8)$. 
Habit: Plants dioecious, clumped or spreading on short rhizomes with densely grouped, intertwining culms. Clumps often up to $2 \mathrm{~m}$ across, $0.5 \mathrm{~m}$ high. Rhizome shortly creeping, 1-3 mm diameter, dark red-brown and covered with tufts of orange-brown to cream hairs; scale leaves chocolate-brown, shiny, broadly triangular, 5-7 mm long, tightly overlapping; cataphylls clasping, dark brown, up to $1.5 \mathrm{~cm}$ long, closely appressed. Culms unbranched, terete, solid, yellow-green, finely marbled, 30-50 cm long, $0.5-0.9 \mathrm{~mm}$ diameter, tightly coiled; lower culm internodes with dense indusium of felt-like, straw-coloured hairs; culm nodes equidistant in upper portions $3-5 \mathrm{~cm}$ apart, up to $1 \mathrm{~cm}$ apart in lower portions; culm sheaths flared from base, truncate, red-brown, straw-coloured at apex, 8-10 cm long, deciduous with age; lamina short, deciduous, $0.5 \mathrm{~mm}$ long. Male spikelets sessile, single, axillary at upper culm nodes, almost totally enclosed by subtending culm sheath, 3-9 per culm, elongate, 5-7 mm long; glumes erect and spiny with an inconspicuous terminal fringe of white hairs, rust-brown, broadly lanceolate $2.5 \mathrm{~mm}$; mucro dark brown, up to $2 \mathrm{~mm}$ long. Male flowers up to 10 flowers per spikelet; tepals 6, membranous, linear-lanceolate, 1.6-2.0 mm long; stamens 3, exserted. Female spikelets 3-9 per culm, sessile and single on upper culm nodes, almost entirely enclosed by culm sheaths, deciduous, elongate, 5-7 $\mathrm{mm}$ long; glumes spiny with terminal fringe of hairs, $5 \mathrm{~mm}$ long, red-brown; mucro $4 \mathrm{~mm}$, strongly reflexed. Female flowers several per spikelet, sessile or shortly pedicellate 1-3 per spikelet; tepals $6,2-3 \mathrm{~mm}$ long, broadly elongate, translucent-straw-coloured; style unbranched stigma plumose, red, $3 \mathrm{~mm}$ long Fruit a unilocular nut.

Flowering: Winter/Spring (May-September). Seed-shed: August-September. Seedlings: not observed.

Affinities: L. spiralis is very similar to L. preissianus in general habit and morphology, but $L$. spiralis has more compact, narrower rhizomes and much smaller male spikelets scarcely emerging from culm sheaths. Female spikelets of $L$. spiralis have a distinctive reflexed spiny mucro on bracts and glumes whereas these are erect in L. preissianus.

Ecological features: Known only from a few populations on deep yellow sands in dry heath in Frank Hann National Park. Starch is present in rhizomes and culms and the plants probably recover after fire.

Conservation status: Possibly highly localized and edaphically restricted to small pockets of yellow sands amongst predominantly deep white sands. Clearly in need of further survey.

Etymology: The specific epithet is from the Latin spiralis, coiled, referring to the culms.

\section{Leptocarpus crassipes J. S. Pate \& K. A. Meney, sp. nov.}

Planta dioica rhizomatibus breviter repentibus, culmis dense fasciculatis, vaginis truncatis, nitidis, caducis, spiculis sessilibus solitariis, caducis. Spiculae foemineae glumis spinosis, spinis prominentibus, reflexis.

Type: South-western Western Australia, S.W. Botanical Province, Kent River between Denmark (34 $\left.58^{\prime} \mathrm{S} 117^{\circ} 21^{\prime} \mathrm{E}\right)$ and Walpole (34⒌ $\left.59^{\prime} \mathrm{S} 116^{\circ} 44^{\prime} \mathrm{E}\right)$, Pate \& Meney KM913, 5 January 1991, (holotype KPBG; isotype PERTH). Growing in permanently inundated swampy depressions.

Habit: Plants dioecious, stout, erect $80-110 \mathrm{~cm}$ tall with tufted rhizomes. Rhizomes lightbrown, branched and shortly creeping with dense laterally spreading root mass and marked bulb-like swellings at points of attachment with culm bases, basal diameter $5 \mathrm{~mm}$, internodes with dense, soft covering of trichomes; strongly aerenchymatous with trabeculae of marginal and central aerenchyma connecting with that of culm bases and roots; scale leaves truncate, 8-10 $\mathrm{mm}$ broad at base, $15 \mathrm{~mm}$ long, pale brown with dark brown striations; cataphylls similar to scale leaves in size, shape and colour but with scarious margins; mucro $2-3 \mathrm{~mm}$ 
long. Culms terete, smooth, unbranched, hollow except at base, blue-green, $1.8-2.6 \mathrm{~mm}$ in diameter, finely pubescent with a reddish flush at culm nodes and immediately above culm sheaths, usually with both taller vegetative culms and sparse shorter reproductive culms present; culms bases distinctly swollen; culm sheaths brown, 10-15 sterile, upper 1-4 fertile, light brown with prominent transparent scarious margins, closely appressed to culms, 11-16 mm long, finally striated; mucro 5-7 mm long encased in translucent margins. Male spikelets ovoid-elongate, $4-6 \mathrm{~mm}$ long, $1.5 \mathrm{~mm}$ broad, in nodding, pedicellate clusters arranged in a loose terminal panicle, 15-40 spikelets per culm; glumes 20-30, broadly lanceolate with scarious margins, $1.5-1.8 \mathrm{~mm}$ long, $0.7-0.9 \mathrm{~mm}$ broad, bearing a mucro $0.1 \mathrm{~mm}$ long. Male flowers: $20-30$ per spikelet, brown, tepals 6 , narrow-linear, 1-1.5 mm
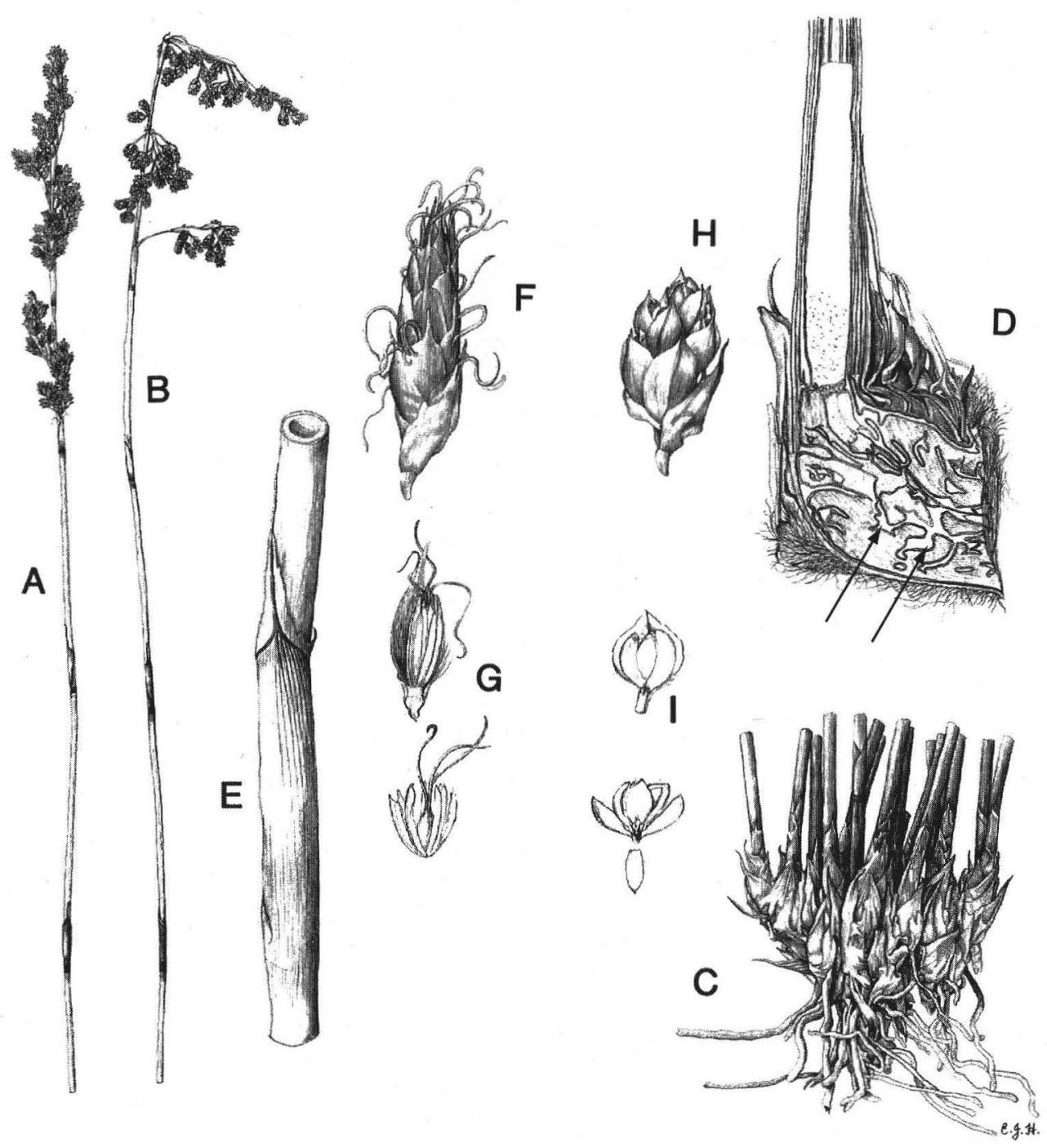

Fig. 6. Leptocarpus crassipes J.S. Pate \& K.A. Meney. A, female culm $(\times 0.4)$; B, male culm $(\times 0.4)$; C, rhizome and lower culm bases $(\times 0.6)$; $\mathbf{D}$, section through rhizome and lower culm showing aerenchyma, indicated by arrow $(\times 2)$; E, culm sheath $(\times 2)$; F, female spikelet $(\times 6)$; $G$, female flower $(\times 7)$; H, male spikelet $(\times 4)$; I, male flower $(\times 3.5)$. 
long, mucronate; stamens 3, not exserted, anthers cream, staminal filaments reddish. Female spikelets dark brown ageing to grey, fusiform, $5-8 \mathrm{~mm}$ long, $1.5 \mathrm{~mm}$ broad in 1 to 3 axillary or terminal clusters, 6-15 per cluster; glumes lanceolate, acuminate, transparent with scarious margins 8-15 mm long, lower 1 or 2 sterile. Female flowers 12 per spikelet; tepals 8, 0.9-1.2 mm long, purple, narrow-filamentous; style divided almost to base, stylar branches 3, purple, $1.5 \mathrm{~mm}$ long. Fruit a turbinate nut $1.2 \mathrm{~mm}$ long, $0.1 \mathrm{~mm}$ broad.

Flowering: Flowers in early summer as water levels in swamps recede. Seed-shed: late summer with seed dispersed by wind or water. Seedlings: dimorphic. When germinating above-ground 1-2 terete first seedling leaves are followed by adult-like culms with scale leaves. Seedlings establishing under water first develop a rosette of 1-15 flattened juvenile leaves. This habit is retained until the seedling emerges above the receding water, at which stage adult-like erect culms are formed.

Ecological features: $L$. crassipes is one of the few species of Leptocarpus in permanently inundated habitats. It is known only from permanent waterholes in swamps in the Kent River area between Denmark and Walpole. It is fire-resistant and contains high levels of starch in the rhizomes.

Etymology: The species epithet is from the Latin crassus, fat and pes, a foot and refers to the swellings on the submerged culm bases where they attach to the rhizome.

Affinities: The taxon shows close affinities to a range of the wetland south-western Australian Leptocarpus species, particularly L. scariosus, but is distinguished by the bulbous culm bases and unusually sparse inflorescences in comparison with cohabiting species.

Conservation status: Since this species might be easily confused with closely related taxa, it may well be more widely distributed than present knowledge indicates. Apparent dependence on permanent water means that susceptibility to lowering water tables might endanger populations.

Loxocarya albipes J. S. Pate \& K. A. Meney, sp. nov.

Planta dioica, caespitosa, rhizomate repenti, dense villoso, culmis teretibus sparse ramosis, striatis atque tuberculatis, vaginis caulinis adpressis, striatis, glabris, spiculis in glomerulis axillaribus vel solitariis.

Type: South-western Western Australia, S.W. Botanical Province, Wongan Hills $\left(30^{\circ} 51^{\prime} \mathrm{S} 116^{\circ} 43^{\prime} \mathrm{E}\right)$. In a single small gravel pit $15 \mathrm{~km} \mathrm{~W}$ of Wongan Hills. Pate $\mathcal{E}$ Meney KM 9304, 10 August 1993, (holotype KPBG; isotype PERTH). Growing in cappings of loose gravel over laterite.

Habit: Plants dioecious, densely tufted with decumbent habit, approximately $50-80 \mathrm{~cm}$ tall, clumps up to $1.5 \mathrm{~m}$ across. Rhizome shortly-creeping, superficial, redbrown, densely villous with continuous covering of white woolly hairs, weathering with age, 3.5-4.5 mm diameter; scale leaves widely-spaced, orange-brown, tightly appressed, 1-3 mm long; cataphylls red-brown, ribbed, $2 \mathrm{~mm}$ long. Culms terete, hollow at base, light green, $0.8-1.2 \mathrm{~mm}$ diameter, $30-70 \mathrm{~cm}$ long, mostly hidden by a dense covering of white hairs; branchlets semi-flattened; culm nodes more or less equidistant, up to 14 per culm; sheaths with scarious margins, red brown, flushed dark red-brown close to point of attachment to nodes, striate, 6-14 mm long, closely appressed, covered with resinous tubercles, sterile sheaths 5-10, spikelet-subtending sheaths 2-7 per culm; lamina present or absent, if present closely appressed, 1-3 mm long. Male spikelets in axillary clusters of $2-6,8-30$ per culm, linear-ovoid, 8-13 mm long, 2-4 mm wide; inflorescence bracts light brown with pronounced scarious margins; apex 5-7 mm wide, 1.5-2.5 mm long, tuberculate; glumes 2.5-3.5 mm long, linear lanceolate; mucro 1-1.5 mm long. Male flowers sessile to very shortly 
pedicellate, 7-12 per spikelet; tepals 3 , with scarious margins, oblong to broadly lanceolate 1.5-2 mm long; stamens 3, exserted. Female spikelets fusiform, 7-10 mm long, $1.5 \mathrm{~mm}$ wide, 2-6 per culm solitary or in a clustered pair; inflorescence bracts striate and tuberculate, red-brown, 8-12 $\mathrm{mm}$ long with 1-2 mm apex; glumes strongly keeled, lanceolate, $5 \mathrm{~mm}$ long with distinct scarious margins; mucro $1.5 \mathrm{~mm}$ long.

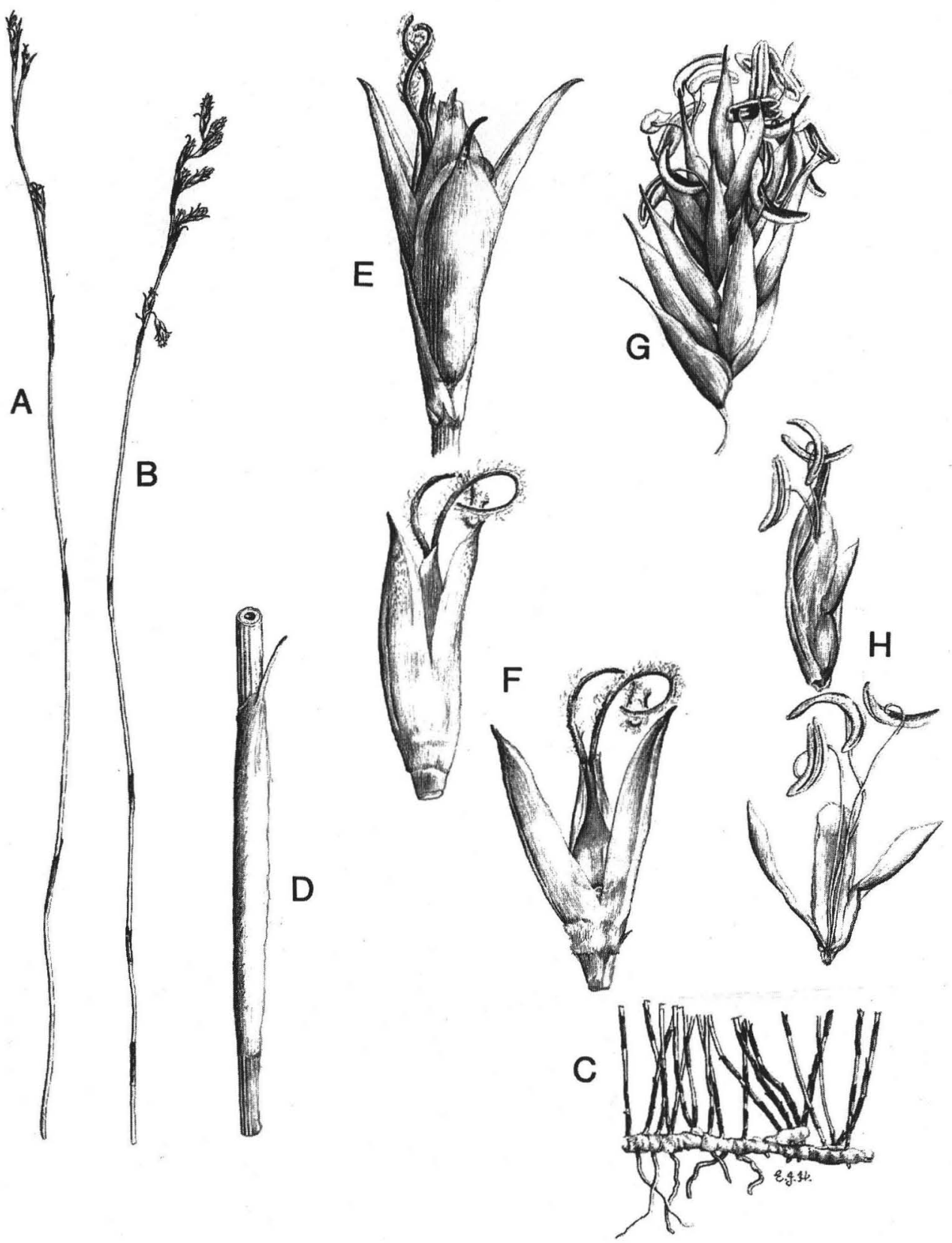

Fig. 7. Loxocarya albipes J.S. Pate \& K.A. Meney. A, female culm $(\times 0.5)$; B, male culm $(\times 0.5)$; C, rhizome $(\times 0.7)$; D, culm sheath $(\times 3)$; E, female spikelet $(\times 7.3)$; F, female flower $(\times 11)$; G, male spikelet (×7.3); H, male flower $(\times 7.3)$. 
Female flowers 2 per spikelet; tepals 3, oblong $2.5 \mathrm{~mm}$ long; style purple, fused; stylar branches up to $5 \mathrm{~mm}$ long; ovary bilocular. Fruit a heart-shaped indehiscent capsule, 3-4 mm long, 1.5-2 mm broad, compressed with a prominent persistent woody stylar beak; capsule splitting loculicidally along the broad axis of the fruit; seeds 2 per fruit, oblong to reniform, $2.2 \mathrm{~mm}$ long, $1 \mathrm{~mm}$ broad, light brown, uniformly tuberculate.

Flowering: August-September. Seed-shed: September. Seedlings: first season's culms sinuose with sterile flattened branches, second-year culms resembling those of adult. Rhizomes creeping, woolly as in adult.

Affinities: Loxocarya albipes shows closest affinity to Loxocarya striata (F. Muell.) L.A.S. Johnson \& B.G. Briggs ined. (= Restio megalotheca nom. illeg.) in habit, fruit characters and rhizome features. This species is typical of the genus Loxocarya, particularly in fruit characteristics and the chemical feature of possessing the unusual non-protein amino acid S-methyl-cysteine (Pate et al 1995).

Ecological features: Loxocarya albipes is known only from a lateritic gravel pit surrounded by mostly agricultural land near Wongan Hills, W.A. Absence of rhizome starch and the superficial location of rhizomes indicate that plants are probably killed by fire.

Conservation status: Probably a disturbance opportunist; further research is urgently required on distribution and mode of recruitment in natural habitats. Only 30 adult plants and several seedlings are currently known, suggesting that the species deserves high-priority status for conservation.

Etymology: The specific epithet is from the Latin albus, white and pes, a foot referring to the densely tomentose, superficially creeping rhizomes.

\section{Loxocarya magna K. A. Meney \& K. W. Dixon, sp. nov.}

Planta dioica, caespite rotundato, magno, rhizomatibus reptantibus, culmis cylindraceis ramis sinuosis compressis spiculas plurimas sessiles vel breviter pedunculatas et plerumque singulas ferentibus.

Type: South-western Western Australia, South-west Botanical Province, Scott River

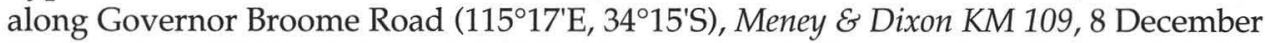
88, (holotype KPBG; isotype PERTH). Growing in shallow sandy soils over lateritic ironstone, often covered by a perched water-table during winter and spring.

Habit: Plants dioecious, forming tall, tightly coiled compact clumps to $1.5 \mathrm{~m}$ tall. Rhizomes creeping, covered with short white-grey hairs, $4-5 \mathrm{~mm}$ wide; scale leaves dull grey, scarious, broadly triangular, 2-2.5 mm long, closely appressed; cataphylls grey-brown, ribbed, closely appressed, $1-1.5 \mathrm{~mm}$ long with a broad apex and short $(0.5 \mathrm{~mm})$, broad lamina. Culms terete, hollow, striate, many-branched, pale-green, 70-100 cm long, 2-3 mm wide at base, branchlets sinuose, flattened; culm nodes more or less equidistant, 5-8 cm apart, approximately 10-15 per culm; sheaths broadly lanceolate appressed, light brown to straw, striate, ovate, 10-12 mm long; lamina 1-3 mm long. Male spikelets mostly formed on second or third order branchlets, 3-10 per branchlet, sessile or pedicellate, 2-3 mm long, ovoid, numerous; glumes obovate, $1.5-1.7 \mathrm{~mm}$ long, straw-brown coloured; mucro up to $1 \mathrm{~mm}$, dark-brown, stout. Male flowers sessile, up to 6 per spikelet; tepals 6, straw-brown, linear 1.5-2 mm long; mucro triangular; stamens 3, exserted. Female spikelets fewer than on males, axillary or terminal, $2-3$ per branchlet, elongate, $8-11 \mathrm{~mm}$ long; glumes rigid, woody, divergent in fruit, 7-11 $\mathrm{mm}$ long. Female flowers one per spikelet, sessile, exceeded by glumes; tepals 3, lanceolate, 1.5-2 mm long; style unbranched, plumose. Fruit a unilocular, dolabriform, indehiscent capsule, 8-11 $\mathrm{mm}$ long, 4-5 $\mathrm{mm}$ wide with prominent woody stylar beak, dehiscing down one side; seed flat grey-brown, $4 \mathrm{~mm}$ long. 
Flowering: September-October. Seed-shed: September-October. Seedlings: First seedling leaves linear. Primary culms of seedlings flattened and bearing numerous elongate, green flattened leaves.

Affinities: Similar in tufted habit and general morphology to Loxocarya striata and to L. cinerea R.Br. but easily distinguished from the former taxa by its unilocular fruits, and from both by the culm height and fruit size.

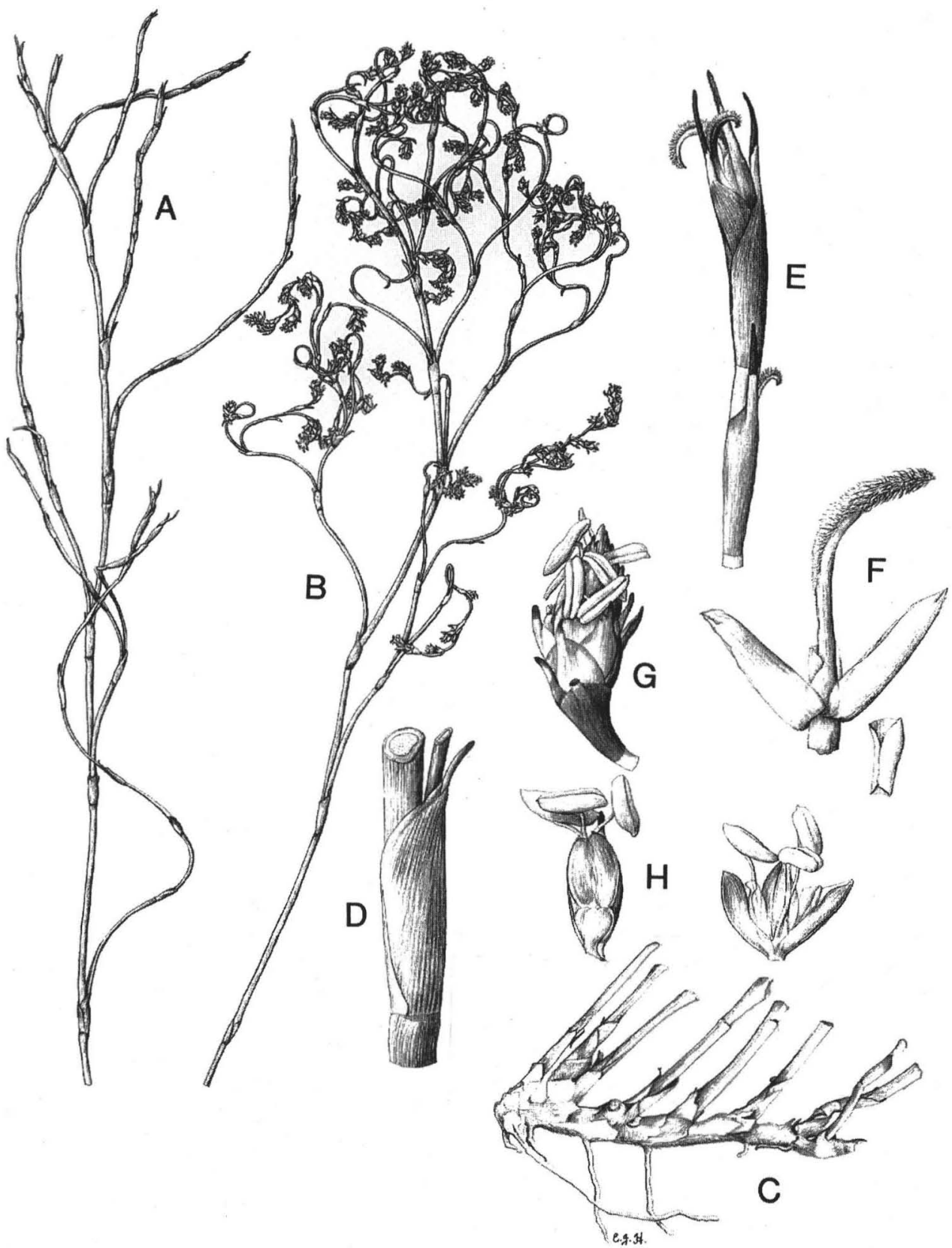

Fig. 8. Loxocarya magna K. A. Meney \& K. W. Dixon. A, female culm $(\times 0.6)$; B, male culm $(\times 0.6)$; C, rhizome and culm bases $(\times 0.5)$; D, culm sheath $(\times 6)$; E, female spikelet $(\times 7)$; F, female flower $(\times 6)$; G, male spikelet $(\times 6)$; $\mathbf{H}$, male flower $(\times 6)$. 
Ecological features: Known from only two locations on remnant ironstone within seasonally inundated heath at Scott River and Ruabon. Plants are killed by fire and regenerate from seed.

Conservation status: Rare and endangered, apparently restricted to two unreserved, small populations on ironstone pavement habitats.

Etymology: The specific epithet is from the Latin magnus, great, referring to the large size of adult clumps.

Onychosepalum microcarpum K. A. Meney \& J. S. Pate, sp. nov.

Planta dioica, demissa, caespitosa, rhizomatibus pilis sparsis instructis, erectis, culmis laevibus, cylindraceis, sinuosis vel erectis, ramis absentibus, vaginis caulinis 1-2, striatis, apice nitidis, spiculis plerumque singulis atque terminalibus.

Type: South-western Western Australia, S.W. Botanical Province, Gingin ( $31^{\circ} 21^{\prime} S$ $\left.115^{\circ} 54^{\prime} \mathrm{E}\right)$ to Cataby $\left(30^{\circ} 45^{\prime} \mathrm{S} 115^{\circ} 33^{\prime} \mathrm{E}\right)$ Meney \& Pate KM 9091, 6 September 90 (holotype KPBG; isotype PERTH). Growing in deep sand.

Habit: Plants dioecious, diminutive, $7-15 \mathrm{~cm}$ tall, tufted. Rhizome ascending, $0.5-0.8 \mathrm{~mm}$ wide, axillary rooting at nodes; internodes sparsely tomentose, reddishbrown with tufts projecting beyond scale leaves; scale leaves straw-coloured, crowded, overlapping, ovoid-triangular with prominent striations, $2-3 \mathrm{~mm}$ long; cataphylls straw-coloured, 3-5 $\mathrm{mm}$ long, ridged, broadly ovate; mucro prominent, 1-2 $\mathrm{mm}$ long. Culms terete, smooth, unbranched $0.3-0.5 \mathrm{~mm}$ wide, sinuose in females to more erect in males; culm sheaths 1-2 per culm, light green-brown, striate, 4-6 mm long; lamina broad, flared, 2-5 mm long. Male spikelets usually solitary and terminal on the culm, occasional culms with a second smaller spikelet arising from the node, ovoid globose, 4-6 mm long, 3-4 mm broad; inflorescence bracts similar to glumes; glumes light brown, broadly lanceolate, 2-2.5 mm long, the lower 7-12 glumes sterile; mucro dark brown $0.5-1 \mathrm{~mm}$ long. Male flowers sessile, 10-20 per spikelet; tepals 6, straw-coloured, 1.8-2 mm long, linear, membranous with blunt apex. Female spikelets narrow-ovoid, 3-4 mm long, 1-1.3 mm broad, 2-3 per culm; inflorescence bracts pale straw-coloured, 1-1.2 mm long; apex exceeding the length of each bract, up to $2 \mathrm{~mm}$; glumes $1.5-2.5 \mathrm{~mm}$ with scarious margins carrying a fringe of hairs, lower 6-8 glumes sterile; mucro 0.8-1.2 mm long. Female flowers 1-2 terminal flowers per spikelet; tepals $6,0.8-1 \mathrm{~mm}$ long, mucronate, transparent, scarious, broadly lanceolate; style 7-8 mm long, undivided; stigma single, purple, exserted $5 \mathrm{~mm}$ beyond the spikelet; ovary unilocular. Fruit a diminutive nut, less than $0.5 \mathrm{~mm}$ long.

Flowering: August-October. Seed-shed: September-October. Seedlings: similar to adult plants.

Affinities: This species is closely similar to Onychosepalum laxiflorum Steud. but differs in possessing diminutive spikelets, usually with several spikelets on each female culm and with several (as opposed to one) internodes per culm. Flower and fruit characteristics are broadly similar to those of Lepidobolus and Catacolea.

Ecological features: Onychosepalum microcarpum is known from three small populations in the Northern Sandplains between Gingin and Badgingarra. It is a short-lived opportunistic species which colonises bare areas of leached deep white and yellow sand, particularly after disturbance. It does not contain appreciable reserves of starch and plants are killed by fire. No information is available on seed longevity.

Conservation status: Conservation status is uncertain. It appears locally abundant but requires further study in view of the restricted distribution and ephemeral nature of the presently known populations.

Etymology: The specific epithet microcarpum is from the Greek mikros, small and karpos, a fruit, referring to the small fruits of the species. 

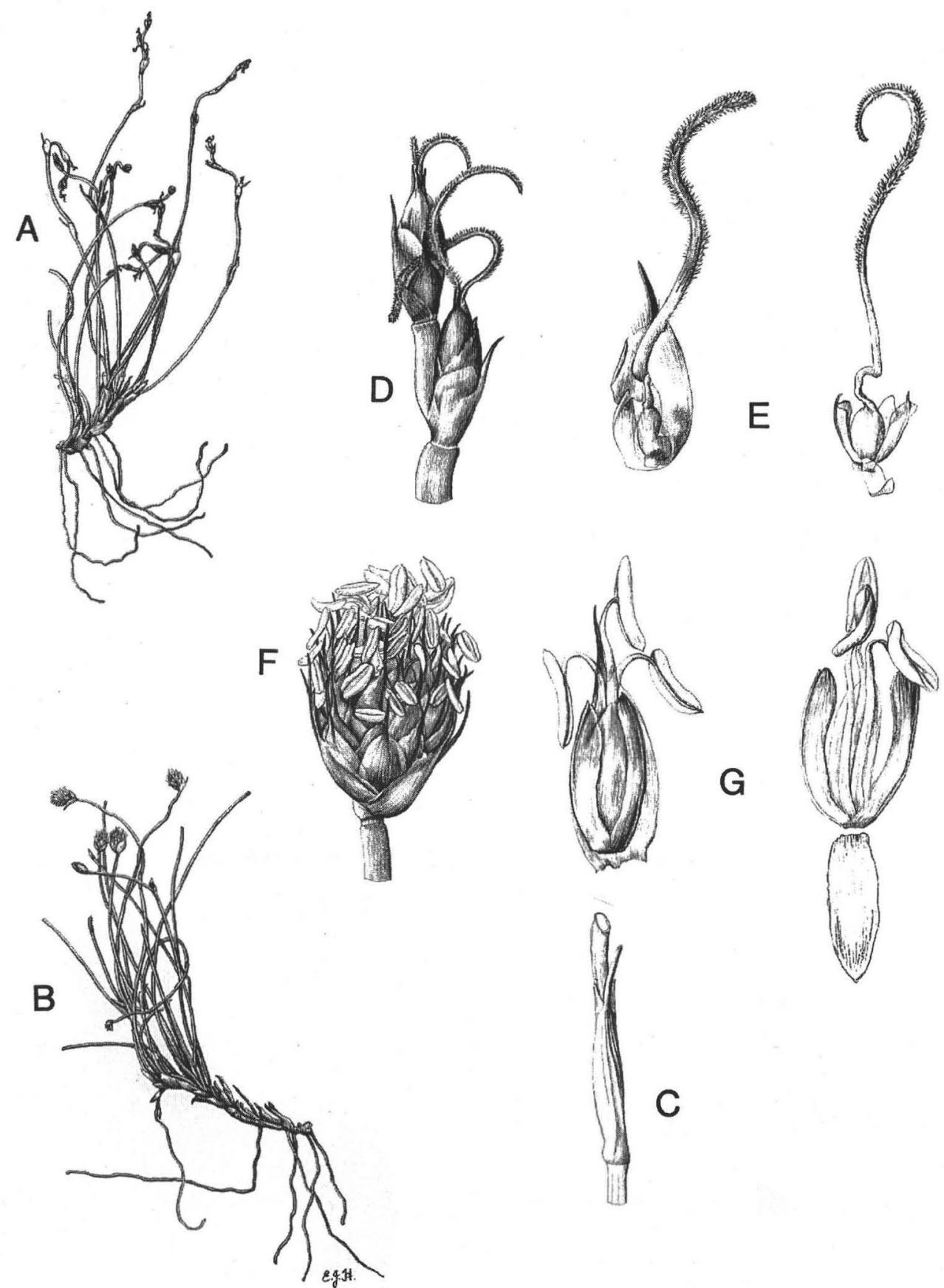

Fig. 9. Onychosepalum microcarpum K.A. Meney \& J.S. Pate. A, female plant $(\times 0.6) ; \mathbf{B}$, male plant $(\times 0.6)$; C, culm sheath $(\times 2.3)$; D, female spikelets $(\times 6)$; E, female flower $(\times 9.2)$; F, male spikelet $(\times 5.4)$; G, male flower $(\times 9.2)$. 


\section{Discussion}

The nine taxa described in this paper represent part of the outcomes of an ongoing study into the Restionaceae and related families in Western Australia. All taxa represent new collections made during the study from botanically well known areas. These species are all restricted and most are threatened, adding to a current list of 20 priority, one endangered and one vulnerable threatened species of Western Australian Restionaceae (Department of Conservation and Land Management 1991, 1995). This represents one quarter of the family in this state, emphasising their importance in conservation programs.

Habitats of the new taxa range from permanently inundated wetlands (Leptocarpus crassipes) and seasonally wet heathlands on perched water tables (Loxocarya magna) to species favouring dryland sites on sand or sand over laterite. Loxocarya magna only grows on ironstone formations in the extreme south west. The plant communities on these formations are considered highly vulnerable and threatened (Gibson et al. 1994) and in urgent need of reservation. Lepidobolus spiralis is unusual in occurring only in sandy habitats over yellow sand subsoil. This habitat also supports a range of other geographically restricted taxa including Brachyloma 'microphylla' T. Bell and K.W. Dixon ined. and gen. nov. aff. Astroloma.

Harperia ferruginipes, Lepidobolus basiflorus and Desmocladus glomeratus are restricted in distribution mostly as a result of extensive clearing for agriculture. The former two are not protected within current reserves and require consideration for protection. Loxocarya albipes is the most critical species for conservation, with only one known population of less than 100 plants restricted to a degraded roadside gravel reserve. Onychosepalum microcarpum and Hypolaena robusta extend over $150 \mathrm{~km}$ and are possibly more widespread than currently known. Further survey is required.

\section{Acknowledgements}

The authors thank Ellen Hickman for providing species illustrations, Drs Barbara Briggs and Lawrie Johnson for authenticating new species and offering helpful suggestions, and Professors Sandro and Erika Pignatti for providing the Latin diagnoses.

This paper is dedicated to Dr Lawrie Johnson on the occasion of his 70th birthday. His vision and enthusiasm for the Restionaceae have contributed much to our understanding of this fascinating and misunderstood Gondwanan family.

\section{References}

Department of Conservation and Land Management (1991) Declared rare and priority flora list. CALM Report, Como, Western Australia.

Department of Conservation and Land Management (1995) Report of the Scientific Ranking Panel. Unpublished report, Como, Western Australia.

Johnson, L. A. S. and Briggs B. G. (1983) Restionaceae. Pp 371-373 in B.D. Morley and H.R Toelken (eds), Flowering Plants in Australia (Rigby: Adelaide, Australia).

Gibson, N., Keighery, B., Keighery, G., Burbidge, A. and Lyons, M. (1994) Floristic survey of the southern Swan Coastal Plain. Unpublished report for the Australian Heritage Commission prepared by the Department of Conservation and Land Management and the Conservation Council of WA Inc. Perth, Western Australia.

Pate, J.S., Rasins, E., Thumfort, P.P., McChesney, C.J. and Meney, K.A. (1995) Occurrence of the unusual amino compound S-methyl cysteine in Australian members of the Restionaceae: biological and taxonomic significance. Australian Journal of Botany 43: 73-84. 